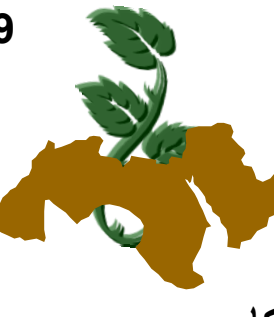

مجلة اتحاد الجامعات العربية

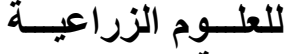

جامعة عين شمس ، الترس ، القاهرة مجلا(17)، عدد (1)، 151-159، اهنم 2009 الإستفادة من قرون الخروب في إنتاج بليل لمسحوق الكاكاو

[12]

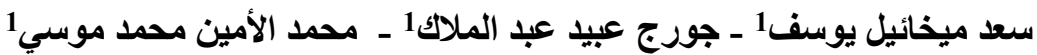

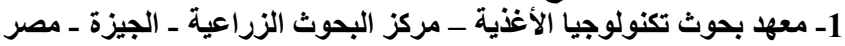

النقص في الفينو لات الكليـة ونشـاط مضـادات الأكسـدة

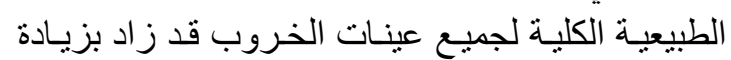
درجة الحرارة ووقت المعاملة بالتحميص.

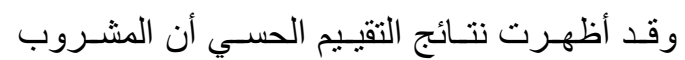
الساخن والكيك المصنع من مسحوق الخروب قد لاقي

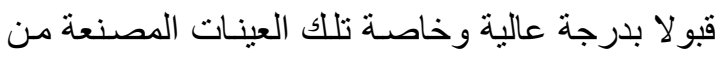
مسحوق الخروب المحمصة علي درجـة حرارة 160

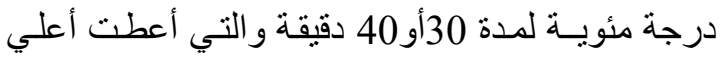

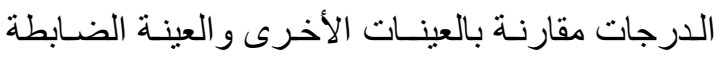

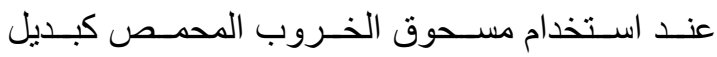
لمسحوق الكاكاو.

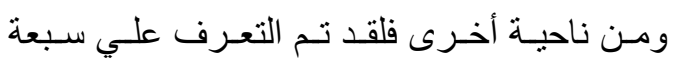

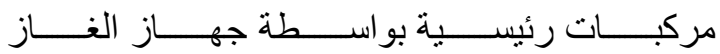

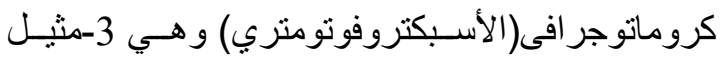
بيوتانال ومثيل بروبانال حيث لوحظ ان هذين المركبين

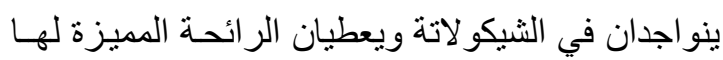

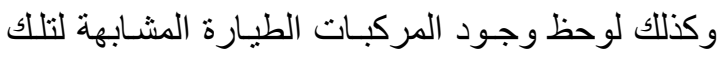

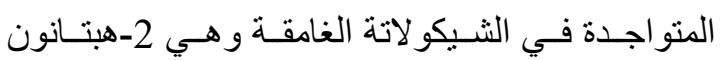

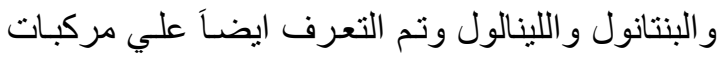
أخري منل نونان-2 اون و الهكسانال.

\section{الملخص العربـي}

تـم دراسـة تـأثير عمليـة تحمـيص الخـروب علـي درجات حرارة وازمنة مختلفة علي التركيب الكيميائي

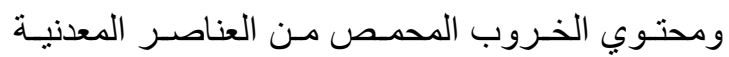

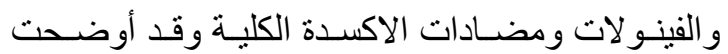

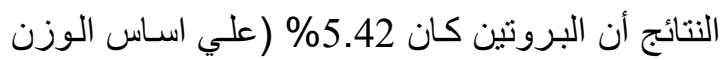

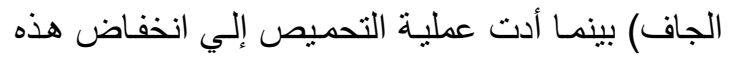

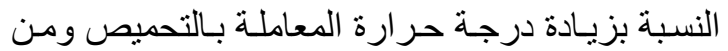
ناحية اخري فلقد لوحظ حدوث انخفاضـاً تدريجياً في لردي

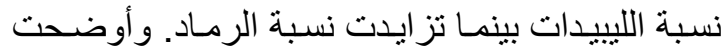

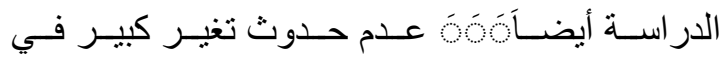
المحتوي من العناصر المعدنية بعد معاملات التحميص لاصن سواء علي 160 أو 170 درجـة مئويـة لأزمنـة مختلفـة. كما أظهرت النتائج حدوث انخفاض تدريجي في كميـة

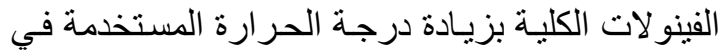

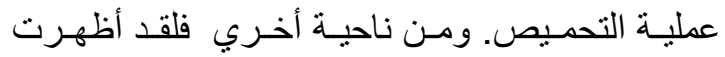

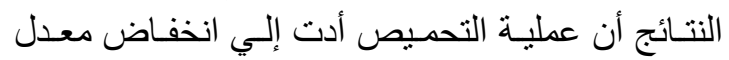

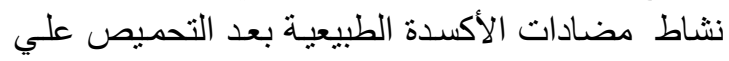

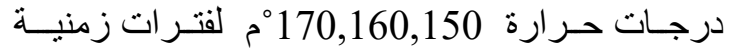

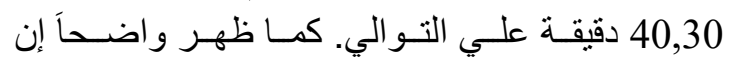

